\title{
An analysis of three distinct approaches to using defamation to protect corporate reputation from Australia, England and Wales, and Canada
}

Article

Accepted Version

Coe, P. (2020) An analysis of three distinct approaches to using defamation to protect corporate reputation from Australia, England and Wales, and Canada. Legal Studies, 40 (4). pp. 1-19. ISSN 1748-121X doi: https://doi.org/10.1017/lst.2020.38 Available at https://centaur.reading.ac.uk/93149/

It is advisable to refer to the publisher's version if you intend to cite from the work. See Guidance on citing.

To link to this article DOI: http://dx.doi.org/10.1017/lst.2020.38

Publisher: Cambridge University Press

All outputs in CentAUR are protected by Intellectual Property Rights law, including copyright law. Copyright and IPR is retained by the creators or other copyright holders. Terms and conditions for use of this material are defined in the End User Agreement. 


\section{CentAUR}

Central Archive at the University of Reading

Reading's research outputs online 


\title{
AN ANALYSIS OF THREE DISTINCT APPROACHES TO USING DEFAMATION TO \\ PROTECT CORPORATE REPUTATION FROM AUSTRALIA, ENGLAND AND \\ WALES, AND CANADA
}

\section{Peter Coe*}

School of Law, University of Reading; Information Law and Policy Centre, Institute of Advanced Legal Studies, University of London, United Kingdom

*Author email: peter.coe@ reading.ac.uk

\section{KEYWORDS}

Media and communications, defamation, corporate reputation, Australia, Canada, England and Wales

\begin{abstract}
The use of defamation law to protect corporate reputation is controversial. Australia, Canada and England and Wales have been at the centre of this debate, as although their defamation laws share many common characteristics, they adopt distinct approaches to allowing companies to sue in defamation. Consequently, in all three jurisdictions defamation law remains a cause of action that is relied upon by companies to protect their reputations. The primary concern of this article is the efficacy of these approaches, ${ }^{1}$ particularly in light of the reforms made to Australia's defamation laws, adopted in 2020, that further restrict the right of corporations to sue in defamation. Ultimately, it argues that the Australian and English and Welsh approaches disproportionately disadvantage companies, particularly small ones, whereas the Canadian approach overprotects corporate reputation. It concludes by offering an alternative way forward that, although not perfect, provides a better balance between the interests.
\end{abstract}

\footnotetext{
*All websites accessed $3^{\text {rd }}$ September 2020. I am grateful to the anonymous reviewers for their valuable feedback. The usual disclaimer applies.

${ }^{1}$ In doing so, it builds on my earlier work in this area. See: Peter Coe, 'A comparative analysis of the treatment of corporate reputation in Australia and the UK' in Paul Wragg and András Koltay (eds.) Research Handbook on Comparative Privacy \& Defamation Law (Edward Elgar Publishing, 2020), 253-269.
} 


\section{PROTECTING CORPORATE REPUTATION IN AUSTRALIA, ENGLAND AND WALES, ${ }^{2}$ AND CANADA}

The $17^{\text {th }}$ of February 2003 was a watershed moment for Australian companies as, up until then, they had unfettered rights to sue for defamation. On that date, the New South Wales (NSW) Defamation Amendment Act $2002^{3}$ introduced section 8A of the Defamation Act 1974. The effect of the provision was to abolish defamation as a cause of action for companies with ten or more employees, and no subsidiaries, at the time of the publication of the alleged defamatory material. As a NSW statute, the provision only applied to publications occurring within the state. It was not, at the time, of national application. Consequently, companies could still bring an action for defamation, even within NSW, for material published outside of the state. ${ }^{4}$

The 1974 Act informed the National Uniform Defamation Law (NUDL), which was adopted by all Australian states and territories in 2006. As a result, section 9 of the Defamation Act 2005, and cognate legislation, ${ }^{5}$ mirrors section 8A of the 1974 Act. Thus, the legislation provides that companies cannot bring claims for defamation; albeit this is subject to exceptions, in that the NUDL entitles not-for-profit corporations, and companies employing less than ten full-time employees, to sue for defamation. ${ }^{6}$

In June 2018, the NSW government published a Statutory Review of the Defamation Act $2005 .^{7}$ Although the Review found that the balance struck by section 9 continues to be appropriate, it recognised the importance of corporate reputation. Consequently, at the time, it left open the possibility of reform in that area, by recommending a review of section 9 to determine whether it should be amended. ${ }^{8}$ Its decision was based on two factors. Firstly, the submission from the NSW Bar Association, which reflects the arguments advanced below, ${ }^{9}$ that section 9 should be expanded to permit all corporations to sue for defamation, on the basis

\footnotetext{
${ }^{2}$ Because section 17(2) of the Defamation Act 2013 makes it clear that the Act only applies to a very limited extent to Scotland this article focusses on the law as it applies in England and Wales. However, because some provisions extend to Scotland (see section 17(3)), the 2013 Act is a 'United Kingdom Act' and is referred to as such.

${ }^{3}$ Section 3, Schedule 1, Clause 5.

${ }^{4}$ Material that is read, heard, or seen outside NSW.

${ }^{5}$ Please note that in that the relevant Act and provisions in the Australian Capital Territory and Northern Territory are section 121 Civil Law (Wrongs) Act 2002 and section 8 Defamation Act 2006 respectively. In all other states and territories, the relevant provision and Act is section 9 Defamation Act 2005 (NSW, Queensland (Qld), Victoria (Vic), South Australia (SA), Tasmania (Tas)).

${ }^{6}$ See section 121(2) Civil Law (Wrongs) Act 2002; section 8(2) Defamation Act 2006; section 9(2) Defamation Act 2005. The scope of these exceptions is explored in greater detail below.

${ }^{7}$ NSW Government, 'Statutory Review Defamation Act 2005' (June 2018).

${ }^{8}$ Ibid. [2.10] and Recommendation 2.

${ }^{9}$ See section 5 .
} 
that the reputations of businesses are also critically important, and are a legitimate interest, that needs to be protected. ${ }^{10}$ Secondly, that Australia's approach does not correspond with the treatment of corporate reputation in other similar jurisdictions which have retained a right of businesses to sue in defamation. These jurisdictions include Canada and, ironically for the reasons explained in section 2, England and Wales $(\mathrm{E} \& \mathrm{~W}){ }^{11}$

Despite these arguments, reforms to Australia's defamation laws proposed in November 2019 by the Council of Attorneys-General, and adopted in 2020, further restrict the right of corporations to sue in defamation. ${ }^{12}$ Under the reforms, the section 9 prohibition for companies with ten or more full-time employees will remain. Additionally, pursuant to a new section $10 \mathrm{~A}(2)$ (this was section $7 \mathrm{~A}(2)$ in previous iterations of the model amendments), ${ }^{13}$ which mirrors the United Kingdom (UK) Defamation Act 2013's section 1(1) and (2) serious harm and serious financial loss tests, companies that employ fewer than ten full-time employees, and are therefore 'excluded' from the section 9 prohibition by virtue of section 9(2)(b), are prevented from bringing an action in defamation unless they can prove that the publication has caused, or is likely to cause, serious harm to the company's reputation and serious financial loss. ${ }^{14}$

Reflecting the treatment of corporate reputation in Australia prior to February 2003, Canada adopts an almost polar-opposite approach to the current Australian position, in that businesses are able to sue in defamation in essentially the same way as natural persons. ${ }^{15}$ Sitting somewhere in the middle of the two is E\&W. As stated above, section 1(2) of the Defamation Act 2013 provides a qualification for the section 1(1) serious harm requirement for bodies trading-for-profit, in that to meet the serious harm threshold they need to demonstrate actual or likely serious financial loss. Thus, although E\&W and Australia now share similar tests, unlike

\footnotetext{
${ }^{10}$ NSW Government above, n7, [2.4].

${ }^{11}$ Ibid. [2.7]. "England and Wales" and "English and Welsh" is hereafter referred to as "E\&W".

${ }^{12}$ All Australian jurisdictions approved the proposed amendments to the Model Defamation Provisions at the July 2020 meeting of the Council of Attorneys-General, where it was 'agreed that all jurisdictions will enact and commence the amendments as soon as possible.' See: Council of Attorneys-General Communiqué $27^{\text {th }}$ July 2020 https:/www.ag.gov.au/sites/default/files/2020-07/Council\%20of\%20AttorneysGeneral\%20communiqué\%20-\%20July\%202020.pdf.

${ }^{13}$ For example, see: Council of Attorneys-General, Model Defamation Amendment Provisions 2020, Report of the Australasian Parliamentary Council's Committee, $12^{\text {th }}$ November 2019, PCC-541 d15: https://www.justice.nsw.gov.au/justicepolicy/Documents/review-model-defamation-provisions/consultationdraft-of-mdaps.pdf.

${ }^{14}$ Model Defamation Amendment Provisions 2020, section 10A(2): PCC-541 d30 (approved by the Council of Attorneys-General, 27 $7^{\text {th }}$ July 2020) (MDAP) https://pcc.gov.au/uniform/2020/Model_Defamation_Amendment_Provisions_2020.pdf.

${ }^{15}$ See generally: Hilary Young, 'Rethinking Canadian Defamation Law as applied to corporate plaintiffs' (2013) 46(2) University of British Colombia Law Review 529-557.
} 
the latter, there is no $\mathrm{E} \& \mathrm{~W}$ provision akin to section 9 and, unlike section $10 \mathrm{~A}(2)$, the section 1(1) and 1(2) tests apply to all bodies that trade for profit, regardless of the number of full-time staff employed by the claimant company.

Australian, Canadian, and E\&W defamation laws share many common characteristics. However, in respect of allowing companies to use defamation to protect their reputations they adopt distinct approaches. Consequently, this article's main concern is not whether corporations should be allowed to use defamation to protect their reputations, as much has already been said on this subject ${ }^{16}$ and, indeed, this article recognises that other causes of action are available to corporate claimants. Rather, its primary purpose is to analyse the efficacy of each country's approach to corporations using defamation as a cause of action. It will pay attention to small companies, particularly in respect of Australia and $\mathrm{E} \& \mathrm{~W}$, because of the challenges created by the former's section 9 (and now section 10A(2)) of the 2005 Act, and the latter's section 1(2) of the 2013 Act. As argued below, this is because these companies are critical, not only to our economies, but also to our societies.

Section 2 provides an overview of the arguments advanced in all three jurisdictions for not allowing businesses to sue in defamation. Section 3 considers why it is imperative to society and democracy to be able to criticise and scrutinise corporations. In doing so it deals with the position in Canada, which arguably overprotects corporate reputation. Section 4 offers a rejoinder to the arguments advanced in sections 2 and 3: that corporate reputation is valuable to society as a whole and to individuals, and therefore merits protection. Section 5 analyses the efficacy of Australia's fewer than ten employees' exemption, and in section 6 alternative causes of action to defamation are considered. Section 7 considers the problems with establishing causation created by section 1(2) of the 2013 Act, and how these challenges could be replicated in Australia by virtue of section 10A(2). Finally, at section 8, it is asserted that the Australian and E\&W approaches (including Australia's introduction of the section 10A(1) and (2) serious harm and serious financial loss tests) disproportionately disadvantage corporations, particularly small ones, whereas the Canadian approach overprotects corporate reputation. Thus, the article offers an alternative way forward for these jurisdictions that, although not perfect, provides a better balance between these two valuable interests.

\footnotetext{
${ }^{16}$ See section 2 below.
} 


\section{AN OVERVIEW OF THE ARGUMENTS AGAINST CORPORATIONS SUIING IN}

\section{DEFAMATION}

In Australia, the rule abolishing the right of corporations to sue in defamation was based on arguments advanced by the Standing Committee of Attorneys-General Working Group of State and Territory Officers on Uniform Defamation Laws (SCAG). ${ }^{17}$ SCAG was of the view that allowing corporations to sue in defamation provided them with an unfair advantage because: ${ }^{18}$ (i) defamation law had been developed to, and was concerned with, the protection of individual reputation, as opposed to the reputation of companies; (ii) companies have other causes of action and remedies to protect, and recover, any losses caused to their reputation available to them, albeit, as discussed in section 6 , these causes of action ${ }^{19}$ are often more difficult to establish than defamation; ${ }^{20}$ (iii) rather than companies using defamation for its intended purpose of protecting their reputation, it could instead be used to silence public debate or criticism; (iv) companies are able to protect their reputations, and mitigate damage caused by defamatory statements, through public relations and advertising campaigns.

SCAG's points reflect the arguments that have been raised against allowing corporations to sue in defamation under $\mathrm{E} \& \mathrm{~W}$ law. As demonstrated by the debates leading to the introduction of the 2013 Act, the fact that businesses were, and still are, able to sue in defamation to protect their reputations was, and remains, a controversial issue. ${ }^{21}$ For instance, the Libel Reform Campaign argued for the exemption of large and medium-sized corporations from suing in defamation unless it could prove malicious falsehood. ${ }^{22}$ Similarly, the Ministry of Justice $(\mathrm{MoJ})^{23}$ recognised that where a company sues an individual or non-governmental organisation, there may be an 'inequality of arms' between the parties, ${ }^{24}$ which is used to stifle criticism of the claimant company's behaviour through the threat of protracted and costly legal proceedings. ${ }^{25}$ Consequently, the MoJ consultation supported the idea that E\&W defamation

\footnotetext{
${ }^{17}$ SCAG Working Group of State and Territory Officers, 'Proposal for Uniform Defamation Laws' (July 2004) <https://www.justice.qld.gov.au/_data/assets/pdf_file/0018/21636/uniform-defamation.pdf>.

${ }^{18}$ Ibid. $14-15$.

${ }^{19}$ For example, the law of injurious (malicious) falsehood.

20 David Rolph, 'Corporations' Right to Sue for Defamation: An Australian Perspective' (2011) 22(7) Entertainment Law Review 195, 196; Matt Collins, 'Protecting Corporate Reputations in the Era of Uniform National Defamation Laws' (2008) 13 Media \& Arts Law Review 447, 456-67.

${ }^{21}$ Alastair Mullis and Andrew Scott, 'The Swing of the Pendulum: Reputation, Expression and the Re-Centring of English Libel Law’ (2012) 63(1) Northern Ireland Legal Quarterly 27, 54.

${ }^{22}$ Libel Reform Campaign, Free speech is not for sale, (2009) $6<$ www.libelreform.org/the-report?start=5>.

${ }^{23}$ MoJ, Draft Defamation Bill: Summary of Responses to Consultation (CP(R)3/11, 2011).

${ }^{24}$ Ibid. [138]-[145].

${ }^{25}$ See also: House of Commons Culture, Media and Sport Committee, 'Press Standards, Privacy and Libel' Second Report of Session 2009-10, Vol. 1, [177] and [178].
} 
law should follow Australia and implement something akin to section 9. ${ }^{26}$ However, the Joint Committee on the Draft Defamation Bill heard evidence that removing the right to sue in defamation from companies might be incompatible with the European Convention on Human Rights. $^{27}$ Thus, rather than following the Australian example, the day before the 2013 Act received Royal Assent, Parliament introduced the section 1(2) serious financial loss qualification.

Although Canada does not prohibit companies from suing in defamation, or provide any E\&W, and now Australian-type, qualification to the cause of action for businesses, the arguments advanced by SCAG have been used by Hilary Young to advocate for Canada to adopt a similar position to Australia and eliminate most corporations' standing to sue in defamation. ${ }^{28}$ However, despite Young's efforts, and unlike in Australia, where SCAG's arguments were influential in the introduction of the section 9 prohibition (and latterly section $10 \mathrm{~A}(2))$, this rationale has yet to be adopted in Canada.

Despite SCAG's arguments, and their adoption by UK and Canadian commentators, they are not uncontroversial. In addition to academic commentary on their validity from all three jurisdictions, ${ }^{29}$ they have been criticised by Philip Ruddock, the former Commonwealth Attorney-General, ${ }^{30}$ as well as the Business Council of Australia, which resisted the 2005 Act reform on the basis that the ability of companies to sue in defamation was necessary to ensure justice and equality before the law. ${ }^{31}$ The NSW Bar Association has also opposed, and campaigned for reform of, section $9 .{ }^{32}$ Consequently, there is no little irony in the fact that the NSW government's Statutory Review of the 2005 Act used the treatment of corporate reputation in $\mathrm{E} \& \mathrm{~W}$ as a persuading factor in its decision to recommend a review of section 9

\footnotetext{
${ }^{26}$ MoJ above, n23, [15].

${ }^{27}$ Joint Committee on the Draft Defamation Bill, 'Oral and Associated Written Evidence' Vol. II (2010-12, HL 203, HC 930-II) 18-19 (Lord Lester), 381-6 (Lord McNally).

${ }^{28}$ Young above, n15. The Canadian Supreme Court has also recognised that defamation law can be used by corporations to 'chill' speech. See: Grant v Torstar Corporation 2009 SCC 61; [2009] 3 SCR 640, [53]; Crookes v Newton 2011 SCC 47; [2011] 3 SCR 269, [36].

${ }^{29}$ From the UK see: Peter Coe, 'The Defamation Act 2013: We Need to Talk about Corporate Reputation' (2015) Journal of Business Law 313, 319-20; Jan Oster, 'The Criticism of Trading Corporations and their Right to Sue for Defamation' (2011) 2 Journal of European Tort Law 255 cf. David Acheson, 'Corporate Reputation under the European Convention on Human Rights' (2018) 10(1) Journal of Media Law 49. From Australia see: Rolph above, n20; Collins above, n20. From Canada see: Young above, n15; Young, 'The Canadian Defamation Action: An Empirical Study' (2017) 95 The Canadian Bar Review 591-630.

${ }^{30}$ See generally Australian Government Attorney-General's Department (AGD), 'Revised Outline of a Possible National Defamation Law' July 2004.

${ }^{31}$ Hugh Morgan, 'Attack on Integrity Lacks Moral Standing' (The Australian Financial Review, 5 April 2005) 63.

${ }^{32}$ For example, see NSW Government above, n7, [2.4].
} 
as, prior to the introduction of the 2013 Act, E\&W very nearly followed Australia by prohibiting companies from bringing a claim in defamation. The enactment and commencement of $10 \mathrm{~A}(2)$ means that companies with fewer than ten employees will only be able to sue in defamation if they are able to prove serious harm by demonstrating actual or likely serious financial loss. Companies with ten or more employees remain barred from suing in defamation. Thus, as stated in section 1, this article argues that the section 9 prohibition and the section $10 \mathrm{~A}(2)$ qualification disproportionately disadvantage companies and that, in relation to smaller entities, the problems with the 2013 Act's section 1(2) qualification are likely to be replicated by the application of section $10 \mathrm{~A}(2)$.

\section{THE VALUE IN BEING ABLE TO CRITICISE CORPORATIONS AND THE 'CANADIAN PROBLEM'}

Facebook's role in recent elections, and the ensuing Cambridge Analytica scandal, and the exponential growth of Amazon are just two examples of the influence that large companies have on the economy, society and politics. ${ }^{33}$ Accordingly, from an E\&W perspective, in Jameel $v$ Wall Street Journal Europe Sprl Baroness Hale stated that 'the power wielded by multinational corporations is enormous and growing' and that the ability to criticise large companies 'may be at least as important in a democracy as the freedom to criticise the government. ${ }^{34}$ Equally, small companies, and their leaders or owners, often play an influential role, and are ingrained, within their local communities. ${ }^{35}$ Due to the influence of companies in the public sphere there is a clear link between speech about corporations with truth finding and democratic

\footnotetext{
${ }^{33}$ Amazon was founded by Jeff Bezos in 1994. At the time of writing Amazon was worth $\$ 1$ trillion, with Bezos' net worth being $\$ 171.6$ billion. B. Hoyle, 'Bezos breaks his own wealth record' The Times, $4^{\text {th }}$ July 2020,14 . By way of further example of the influence of large companies in the UK generally, in 2010 the Conservative and Liberal Democrat coalition government announced the creation of a Business Advisory Group, consisting of industry leaders, to assist the Prime Minister and senior ministers with 'high level' business and economic advice. The group operated until 2016: https://www.gov.uk/government/new s/business-advisorygroup-announced. In 2017 the UK government set up a similar group to advise on Brexit: https://www.ft. com/content/67001056-5b39-11e7-9bc8-8055f264aa8b. And, in 2020, Liz Truss, the International Trade Secretary, launched eleven trade advisory groups, from a variety of industries, to provide advice 'that will be used to help inform the government's negotiating position' during trade talks with other countries: https://www.gov.uk/government/news/liz-truss-brings-key-industries-closer-to-trade-negotiations. ${ }^{34}$ [2007] 1 AC 359, [158]. Similarly, in the United States, Justice Scalia has stated that corporations are the 'principal agents of the modern economy.' See: Citizens United v Federal Election Commission 558 US 310 (2010), 929.

35 The UK's Federation of Small Businesses (FSB) states that: 'Small businesses and the self-employed are at the heart of our communities. This is evident in their willingness and ability to employ those furthest from the labour market, their support for local schools and colleges, and their volunteering activities on local issues.' https://www.fsb.org.uk/.
} 
discourse: ${ }^{36}$ as Devan Desai has stated, the conduct of businesses is very often a matter of public importance ${ }^{37}$ that, as the Canadian courts have recognised, goes beyond the commercial sphere ${ }^{38}$ and is integral to social and political decision-making, ${ }^{39}$ drawing attention to corporate conduct that raises issues of public interest ${ }^{40}$ and consumer protection. ${ }^{41}$

Therefore, ensuring that the ability to criticise the conduct of companies of all sizes is protected is imperative to democracy and the health of our societies. ${ }^{42}$ However, as argued in the following section corporate reputation is itself valuable to these interests. Ultimately, an appropriate balance needs to be found between being able to criticise companies and companies being able to protect their reputation. The remainder of this article will argue that, as it stands, this balance is not being appropriately struck in all three jurisdictions by the respective defamation laws. ${ }^{43}$ In Australia and E\&W, the underlying rationale of section 9 and the new section 10A(2), and section 1(2) of the 2013 Act respectively, was to prevent companies from 'chilling' free speech. Yet, inadvertently, their effects are perhaps more acutely felt by smaller companies without the resources to protect their reputation in other, non-legal, ways. ${ }^{44}$ At the opposing end of the spectrum, in Canada, companies of all sizes are disproportionately protected, which has resulted in the controversial use by corporations of SLAPP (Strategic Lawsuit Against Public Participation) law suits.

\section{The Canadian problem}

The position in Canada differs to Australia and E\&W in that Canadian defamation law treats corporate claimants in the same way as individuals, meaning there is no bar on, or qualification to, companies bringing a claim in defamation. This means that Canadian companies of any size are not faced with the same challenges that are explored in the following sections of this article as companies in Australia and E\&W.

\footnotetext{
${ }^{36}$ Young above, n15, 555.

${ }^{37}$ Devan R. Desai, 'Speech, Citizenry, and the Market: A Corporate Public Figure Doctrine' (2013) 98 Minnesota Law Review 455, 462-466.

${ }^{38} R v$ Guingard 2002 SCC 14, [2002] 1 SCR 472, [23].

${ }^{39}$ Irwin Toy Limited $v$ Quebec (AG) [1989] 1 SCR 927, 970-971.

${ }^{40}$ Daishowa Incorporated $v$ Friends of the Lubicon (1998), 158 DLR (4 $\left.{ }^{\text {th }}\right) 699,78$ ACWS (3d) 861, 729-730.

${ }^{41}$ Ibid.

${ }^{42}$ Douglas A. Kysar, 'Preferences for Processes: The Process/Product Distinction and the Regulation of Consumer Choice' (2004) 118(2) Harvard Law Review 525, 535. See generally: Chris Dent and Andrew Kenyon, 'Defamation Law's Chilling Effect: A Comparative Analysis of Australian and US Newspapers' (2004) 9(2) Media \& Arts Law Review 89.

${ }^{43}$ Other causes of action are available. Some of these are considered in section 6 below.

${ }^{44}$ See section 4 below.
} 
As argued above, being able to appropriately criticise companies is fundamentally important to society and democracy. Thus, the Supreme Court of Canada's (SCC) decision in Hill $v$ Church of Scientology of Toronto ${ }^{45}$ that, in applying the values of the Canadian Charter of Rights and Freedoms, found the common law of defamation to be neither unduly restrictive nor inhibiting of free speech, is troubling in the context of corporate claimants and the country's prevalence of SLAPP litigation. Within this arena arguably the Canadian position goes too far, and disproportionately protects corporate reputation to the detriment of free speech. SLAPP litigation, which is typically (although not exclusively) used by companies to prevent criticism that may or may not be defamatory, ${ }^{46}$ present a particular problem in Canada, where they are used by companies to stifle criticism, ${ }^{47}$ rather than to vindicate reputations or obtain awards for damage that has actually been suffered.

In recent years provincial anti-SLAPP laws have been introduced. For example, British Columbia introduced the Protection of Public Participation Act 2019, which mirrors the provisions found in Ontario's Courts of Justice Act 1990, that were introduced by the Protection of Public Participation Act 2015. ${ }^{48}$ Both pieces of legislation provide a preliminary pretrial procedure for a defendant to seek dismissal of a claim where the litigation arises out of a defendant's expression on a matter of public interest. ${ }^{49}$ The initial burden of proof is on the defendant to satisfy the judge on the balance of probabilities that the proceeding arises from an expression made by them that relates to a matter of public interest. ${ }^{50}$ If this "threshold requirement ${ }^{51}$ is overcome, the burden shifts onto the claimant to establish on the balance of probabilities that, firstly the proceeding has substantial merit ${ }^{52}$ and, secondly, that the defendant has no valid defence in the proceeding. ${ }^{53}$ In addition to the 'merits-based hurdle, ${ }^{54}$ the claimant has to clear a 'public interest hurdle' ${ }^{55}$ by satisfying the judge on the balance of probabilities

\footnotetext{
45 [1995] 2 SCR 1130; Goddard v Day (2000) 194 DLR 559.

${ }^{46}$ From the US see: Gordon v Marrone 590 NYS 2d 649, 656 (1992). See also: Penelope Canan and George W. Pring 'Studying Strategic Lawsuits Against Public Participation: Mixing Quantitative and Qualitative Approaches' (1988) 22(2) Law \& Society Review 385, 387.

${ }^{47}$ Susan Lott, 'Corporate Retaliation Against Consumers: The Status of Strategic Lawsuits Against Public Participation (SLAPPs) in Canada' (2004) https://www.piac.ca/wp-content/uploads/2014/11/slapps.pdf; Young above, n14, 559-560; https://www.wcel.org/blog/new-victory-anti-slapp-law-bittersweet; https://www.cbc.ca/news/canada/british-columbia/legislature-passes-anti-slapp-1.5049927.

${ }^{48}$ See sections 137.1 to 137.5 of the Courts of Justice Act 1990.

${ }^{49}$ Courts of Justice Act 1990 section 137.1; Protection of Public Participation Act 2019 section 2.

${ }^{50}$ Ibid. section 137.1(3); section 4(1)(a) and (b).

511704604 Ontario Limited v Pointes Protection Association 2018 ONCA 685, [50]-[56] per Doherty J.A.

52 Courts of Justice Act 1990 section 137.1(4)(a)(i); Protection of Public Participation Act 2019 section $4(2)(a)(i)$.

${ }^{53}$ Ibid. section 137.1(4)(a)(ii); section 4(2)(a)(ii).

${ }^{54} 1704604$ above, n51, [67]-[84].

55 Ibid. [85]-[101].
} 
that the harm likely to be, or that has been, suffered by them as a result of the defendant's expression is sufficiently serious that the public interest in permitting the proceeding to continue outweighs the public interest in protecting that expression. ${ }^{56}$ Finally, pursuant to the costs regime introduced by the statutes, if a defendant is successful on the motion, the judge should start from the premise that the defendant should receive costs on both the motion and in the proceeding on a full indemnity basis, as opposed to the usual partial indemnity basis. ${ }^{57}$

This legislation, and its subsequent interpretation by the Ontario Court of Appeal (OCA), and more recently by the SCC, in 1704604 Ontario Limited v Pointes Protection Association, ${ }^{58}$ which addressed the limits of the provisions, raises several issues. The first relates specifically to the OCA's and SCC's interpretations of the statute. In relation to the public interest test in the threshold requirement, which is not defined by the statutes, Doherty J.A., in delivering the OCA's unanimous judgment, ${ }^{59}$ found that the concept is 'broad' ${ }^{\prime 60}$ and that the determination must be made 'objectively, having regard to the context in which the expression was made and the entirety of the relevant communication. ${ }^{61}$ He held that while 'there is no exhaustive list of topics ${ }^{62}$ that can be considered 'public interest,' certain topics inevitably will be ${ }^{63}$ and that a matter of public interest has to be distinguished 'from a matter about which the public is merely curious or has a prurient interest. ${ }^{64}$ In expanding on this, Côté J., in giving the SCC's unanimous judgment, stated that the quality of the expression, and motivation behind it, are relevant to the test, and that the expression may be assessed with regard to the core values underlying free speech, 'such as the search for truth, participation in political decision making, and diversity in forms of self-fulfilment and human flourishing.' ${ }^{65}$ Thus, although the threshold requirement is not an onerous test for the defendant to overcome, neither, it is submitted for the reasons below, are the merits-based and public interest hurdles imposed on the claimant.

\footnotetext{
${ }^{56}$ Courts of Justice Act 1990 section 137.1(4)(b); Protection of Public Participation Act 2019 section 4(2)(b).

${ }^{57}$ Ibid. section 137.1(7); section 7(1).

582018 ONCA 685; 2020 SCC 22; Fortress Real Developments Inc. v. Rabidoux 2018 ONCA 686; Platnick v. Bent 2018 ONCA 687; Veneruzzo v. Storey 2018 ONCA 688; Armstrong v. Corus Entertainment Incorporated 2018 ONCA 689; Able Translations Ltd. v. Express International Translations Incorporated 2018 ONCA 690.

${ }^{59}$ Ibid. (1704604). Brown and Huscroft JJ.A concurring.

${ }^{60}$ Ibid. [65].

${ }^{61}$ Ibid.

${ }^{62}$ Ibid. [59].

${ }^{63}$ Ibid. Such as the 'conduct of governmental affairs and the operation of the courts.'

64 Ibid. [61]

652020 SCC 22, [73]-[82].
} 
In respect of the first stage of the merits-based hurdle Doherty J.A. was clear that the purpose of section 137.1 was not to introduce de facto summary judgment motions. ${ }^{66}$ Rather, they are 'screening' motions ${ }^{67}$ that should only involve determining whether, on an examination of the motion record, 'there are reasonable grounds to believe that a reasonable trier could accept the evidence. ${ }^{68}$ Accordingly, the role of the motion judge is to determine whether it 'could reasonably be said, on an examination of the motion record, that the claim has substantial merit. ${ }^{69}$ In the SCC's view this means that the proceeding must 'have a real prospect of success...that, while not amounting to a demonstrated likelihood of success, tends to weigh more in favour of the [claimant]. ${ }^{70}$ In the OCA, Doherty J.A. stated that the second element of this hurdle does not require the claimant to address all of the defendant's possible defences and prove that none have any validity. ${ }^{71}$ Rather, according to Côté J. in the SCC, it places an evidentiary burden on the defendant to advance any proposed 'valid defence' which would then place an onus on the claimant to demonstrate only that there are 'grounds to believe' that none of those defences 'have a real prospect of success'. ${ }^{72}$ According to both Doherty J.A. in the OCA and Côté J. in the SCC the final, public interest hurdle, is the 'heart' or the 'crux' of Ontario's anti-SLAPP legislation. ${ }^{73}$ Although the harm to the claimant can be monetary or non-monetary, they must provide some basis on which the harm or potential harm can be assessed. ${ }^{74}$ Consequently, if the claimant overcomes the merits hurdle, a common sense reading of the claim, supported by sufficient evidence to draw a causal connection between the challenged expression and damages that are more than nominal will often suffice. ${ }^{75}$ It therefore appears that where a claimant is able to sufficiently demonstrate serious harm resulting from the expression, even at a preliminary stage, this hurdle will be cleared.

Secondly, and more broadly, it highlights the fact that despite the problem of SLAPP litigation receiving attention from academic commentators ${ }^{76}$ and provincial governments, at

\footnotetext{
662018 ONCA 685, [78].

${ }^{67}$ Ibid. [73]-[74].

${ }^{68}$ Ibid. [75].

${ }^{69}$ Ibid.

702020 SCC 22, [49], per Côté J.

712018 ONCA $685[83]$.

722020 SCC 22, [55]-[60].

732018 ONCA 685 [86]; 2020 SCC 22, [18], [3], [33], [48], [61], [82].

${ }^{74}$ Ibid. (2018 ONCA 685), [88].

75 Ibid. [90].

${ }^{76}$ Lott above, n47; Young above, n15. See also: Vincent Pelletier et al 'Strategic Lawsuits against Public Participation (SLAPPs) Report 2009' $9^{\text {th }}$ August 2008) Uniform Law Conference of Canada https://www.ulcc.ca/en/annual-meetings/235-2008-quebec-city-qc/civil-section-documents/448-strategiclawsuits-against-public-participation-slapps-report-2008?showall=\&limitstart=.
} 
the time of writing, in addition to Ontario and British Columbia, only Quebec ${ }^{77}$ has introduced similar legislation that operates as a safeguard against these suits. ${ }^{78}$ Finally, and leading on from the second point, the problem presented by SLAPP suits is not confined to corporations but is more acute with corporate claimants because of the 'inequality of resources and power between most corporations and most individuals or small organisations who are likely to be subject to these suits. ${ }^{79}$ Unlike defamation, which has not been used by larger companies to stifle criticism to the extent that was perhaps feared, ${ }^{80}$ it seems that in Canada, the threat of defamation action, made through the vehicle of SLAPP litigation, is employed by larger companies as a reputation management tool to achieve what they cannot achieve in law: to prevent critical speech that has not been proven to be defamatory. ${ }^{81}$ SLAPP suits are effective at achieving this because they put defendants into a 'catch-22' situation: they either have to incur what can be the significant cost of defending the litigation, knowing that even if they are successful, a costs award may not cover the full expense of their legal fees, ${ }^{82}$ or they retract their statement, or choose not to publish what could be valuable public interest speech about a particular corporation.

\section{THE VALUE OF CORPORATE REPUTATION}

\section{(a) Confining defamation law to individuals and the value of corporate reputation}

Arguably, the proposition that the law of defamation should only be concerned with individual reputation is fuelled by the problematic precondition that defamation actions by corporations are dependent upon those companies having a reputation that can be damaged as, Jan Oster states, reputation is, 'at first glance', a characteristic attributed to individuals. ${ }^{83}$ Despite Canadian corporations enjoying the same rights to sue in defamation as individuals, this argument has gained traction there by virtue of the SCC's emphasis on dignitary rather than proprietary aspects of reputation. ${ }^{84}$ This is because, in its treatment of reputation when

\footnotetext{
${ }^{77}$ On the $4^{\text {th }}$ of June 2009 an Act to amend the Quebec Code of Civil Procedure to prevent improper use of the courts and promote freedom of expression and citizen participation in public debate came into force. The Act amended article 54 in Chapter III of Title II of Book I of the Code by giving judges powers to 'impose sanctions for improper use of procedures.'

http://www2.publicationsduquebec.gouv.qc.ca/dynamicSearch/telecharge.php?type=5\&file=2009C12A.PDF.

${ }^{78}$ Similar legislation has been proposed in Nova Scotia and New Brunswick but in both provinces the Bills were not passed.

79 Young above, n15, 561.

${ }^{80}$ See section 4.

81 Young above n15, 562.

${ }^{82}$ Although it appears that in Ontario and British Columbia this is not the case (see above, n57).

${ }^{83}$ Oster above, n29, 258.

${ }^{84}$ Robert C. Post, 'The Social Foundations of Defamation Law: Reputation and the Constitution' (1986) 74

California Law Review 691.
} 
balancing the right with freedom of expression, it has consistently described the importance of reputation from a dignity and autonomy perspective, rather than in terms of property. ${ }^{85}$

Despite these arguments in favour of limiting the tort to individuals, defamation law is used to intervene to protect corporate reputation in all three jurisdictions. In Australia, during debates prior to the introduction of the 2005 Act, Philip Ruddock was of the view that although corporations differ from natural persons in the type of reputation they have, they nevertheless have reputations that can be assailed. Consequently, in his view, providing companies with the mechanisms to protect their reputation is also important. ${ }^{86} \mathrm{In} \mathrm{E} \& \mathrm{~W}$, in Jameel, Lords Bingham, Hope and Scottall agreed that corporate reputation is a thing of value, ${ }^{87}$ with Lord Hoffman stating that it is an asset as it attracts customers. ${ }^{88}$ In Dixon $v$ Holden it was held that reputation is potentially more valuable than other property. ${ }^{89}$ Similarly, in RWDSU, Local $558 v$ PepsiCola Canada Beverages (West) Limited the SCC found that "protection from economic harm is an important value capable of justifying limitations on freedom of expression.' 90

The arguments in favour of this approach are inter alia, the fact that Robert Post's reputation as property provides a conceptual basis for corporations to sue in defamation ${ }^{91}$ to protect corporate 'goodwill', ${ }^{92}$ and the 'value' attributed to corporate reputation, not only to companies themselves, but to communities within which they operate, and the wider economy. In respect of the former, according to Post, there are: ' ... aspects of modern defamation law that can be understood only by reference to the concept of reputation as property, as, for example, the fact that corporations and other inanimate entities can sue for defamation. ${ }^{93}$ Post's thesis that reputation as property provides a conceptual foundation for companies to sue in defamation corresponds with Oster's view, who has argued that 'it is a distinctive feature of a company's suit for defamation that it may exclusively be explained by the conception of reputation as

\footnotetext{
${ }^{85}$ Young above, n15, 548-549; Grant v Torstar Corporation 2009 SCC 61; [2009] 3 SCR 640, [58], [111]; WIC Radio Limited $v$ Simpson 2008 SCC 40; [2008] 2 SCR 420, [2]; $R$ v Lucas [1998] 1 SCR 439; 157 DLR $\left(4^{\text {th }}\right)$ 423, 463.

${ }^{86}$ AGD above, n30, 38-39. As discussed below, the need for such a mechanism is particularly acute in the context of smaller companies who do not have the means to deal with attacks on their reputation.

${ }^{87} \mathrm{n} 34$ above, [91].

${ }^{88}$ Ibid. [26] per Lord Bingham; [101] per Lord Hope; [120] per Lord Scott. See also Derbyshire County Council v Times Newspapers Ltd [1993] AC 534, 547.

${ }^{89}$ Dixon v Holden (1868-69) LRR 7 Eq 488, 492.

902002 SC 8; [2002] 1 SCR 156, [72].

${ }^{91}$ As noted above this does not seem to be the case in Canada.

${ }^{92}$ Economic loss as a result of a depreciation in corporate goodwill is discussed in section 7 below.

${ }^{93}$ Post above, n84, 696; Oster above, n 29, 278.
} 
property. ${ }^{94}$ Thus, the value of reputation is determined by the market in the same way as any property loss is measured. ${ }^{95}$ As Dario Milo suggests, the notion of reputation as property reflects the image of the market society; individuals, he argues, are connected through the institution of the market. ${ }^{96}$ Accordingly, Post advances the argument that the concept of reputation as property is reputation in the marketplace; a notion of reputation that: 'can be understood as a form of intangible property akin to goodwill...acquired as a result of an individual's efforts and labour. ${ }^{, 97}$ Hence, if reputation is injured, the resulting loss is financially quantifiable. ${ }^{98}$ The argument for the wider value of corporate reputation is that the performance of economies, and the continued social and economic development of communities, are linked to the success of corporations of all sizes. ${ }^{99}$ As the European Court of Human Rights acknowledged in Steel and Morris v United Kingdom, ${ }^{100}$ in addition to the public interest in open debate about business practices, there is a competing interest in protecting the commercial success and viability of companies, for the benefit of shareholders and employees, but also for the wider economic good.' 101

\section{(b) Small companies and the 'flawed' 'inequalities of arms' argument}

There is a further, albeit controversial argument, in favour of allowing companies to sue in defamation that is significant to smaller companies: the arguments advanced in section 2 above by commentators and pressure groups in all three jurisdictions in favour of not allowing corporations to sue in defamation were and are focused almost exclusively on large companies and, in any event, are potentially inflated. According to Young, in Canada, 'defamation law has become a weapon in [corporations'] brand management arsenal.' ${ }^{102}$ However, in a later article setting out the results of a quantitative study looking at defamation actions brought by corporate claimants between 1973 and 1983 and 2003 and 2013 she acknowledges that the percentage of corporate defamation cases have in fact 'not increased greatly over the time periods examined' and, in any event, they resulted in liability 'significantly less often in the

\footnotetext{
${ }^{94}$ Ibid. (Oster) 259. See also: The Metropolitan Saloon Omnibus Company (Limited) v Hawkins (1859) 4 Hurlstone \& Norman Exchequer Reports (H\&N) 87 per Pollock CB, 90.

95 Oster above, n29, 259; Dario Milo, Defamation and Freedom of Speech (Oxford University Press, 2008 ), 27.

96 Ibid. (Milo).

${ }^{97}$ Post above, n84, 693.

${ }^{98}$ Milo above, n95, 27.

99 John Smythe et al. Corporate Reputation: Managing the New Strategic Asset (Random House 1992) 4.

100 (2005) 41 EHRR 22.

${ }^{101}$ Ibid. [94]. In the UK, see section 172(1)(d) of the Companies Act 2006, which requires directors to take account of 'the impact of the company's operations on the community and the environment'.

102 Young above, n15, 560-563.
} 
later period than in the earlier period. ${ }^{\prime 103}$ Similarly, in Australia, a perceived, although not necessarily actual, increase in inappropriate corporate defamation actions was used to justify the decision to prohibit businesses with ten or more employees from suing in defamation. ${ }^{104} \mathrm{In}$ the UK, as we have seen above, prior to the introduction of the 2013 Act, arguments were advanced that defamation law was being used by companies to stifle criticism, thereby creating an 'inequality of arms' between deep-pocketed corporate claimants and defendants. ${ }^{105}$ Undoubtedly, in some cases this was, and remains, true, as demonstrated by the use of SLAPP litigation in Canada. However, evidence suggests that large companies seldom brought defamation claims prior to the introduction of the 2013 Act and have continued with this practice since the Act came into force. ${ }^{106}$ This is because large corporations can call on alternative, non-legal, methods, such as 'counter publicity' campaigns and expensive 'reputation insurance', ${ }^{107}$ to protect their reputations and to mitigate any damage caused. To the contrary, as observed by SCAG, smaller companies do not have the same financial, marketing and public relations resources as large companies to absorb attacks on their reputation. ${ }^{108}$ Although it can be expensive, for these smaller companies, defamation provides a mechanism to protect their reputation that, for the reasons discussed in section 6 is, in some cases, preferable to other causes of action. ${ }^{109}$ Thus, it is submitted that the arguments advanced in all three jurisdictions relating to corporate defamation claims being used to stifle free speech are not entirely without basis, yet are flawed. The cause of the concern was, and is, large companies, yet it seems as though they tend not to use defamation as they have alternative methods at their disposal. On the other hand, smaller companies, who have been largely forgotten about in these debates, and may be of more limited means than defendants, do not always have these resources at their disposal. Therefore, although defamation is by no means a 'cheap option', they are more likely to rely on it as a cause of action which, in E\&W, for the

\footnotetext{
${ }^{103}$ Young above, n29, 594-595.

${ }^{104}$ Submission to the Joint Parliamentary Committee Appointed to Conduct Pre-Legislative Scrutiny of the Draft Defamation Bill (12 July 2011), 3 http://www.lawcouncil.asn.au; Rolph, 'A Critique of the National, Uniform Defamation Laws' (2008) 16:3 Torts Law Journal 207, 217.

105 See section 2.

106 Brett Wilson LLP, 'Defamation Act 2013: A summary and overview six years on' Inforrm $29^{\text {th }}$ January 2020 https://inforrm.org/2020/01/29/defamation-act-2013-a-summary-and-overview-six-years-on-part-1-sections-1to-3-brett-wilson-llp/.

107 Paul. J. Davies 'Insurance for groups to restore reputations' The Financial Times $8^{\text {th }}$ May 2011 https://www.ft.com/content/8a61e98a-79a3-11e0-86bd-00144feabdc0.

108 NSW Government above, n7, [2.8].

${ }^{109}$ Despite a claimant's prospect of success, litigation of any kind can be damaging, and can cause more damage to the claimant than the alleged defamatory statement. This is illustrated by the McLibel litigation (McDonald's Corporation v Steel \& Morris [1997] EWHC QB 366) which became the longest libel case in UK history. Although McDonalds 'won', the victory was pyrrhic, in that it cost them approximately $£ 10$ million and was considered a public relations disaster. See generally: http://news.bbc.co.uk/1/hi/uk/4266741.stm.
} 
reasons explored in section 7 , is now potentially far more difficult for them to employ due to the section 1(2) qualification. Similarly, in Australia, the section 9 prohibition and the section $10 \mathrm{~A}(2)$ qualification, expose small companies to attacks on their reputation. ${ }^{110}$

In conclusion, in many situations, a company's reputation is vital, not only for its prosperity, but also its existence. As discussed in section 1, this is one of the factors that encouraged the NSW Government to recommend a review of section 9. ${ }^{111}$ Moreover, as advanced above, the 'health' of a company's reputation can directly affect the overall state of the business which, in turn, can have a significant impact on the local community in which it is based, regardless of its size, having the potential to indirectly effect many individuals. As a result, it is arguable that the reputation of businesses is at least as important as the reputation of individuals. ${ }^{112}$

\section{WHY AUSTRALIA'S FEWER THAN TEN EMPLOYEES EXEMPTION IS FLAWED}

As explained in section 1, Australia's NUDL exempts companies with fewer than ten employees from the general prohibition that corporations cannot sue in defamation, ${ }^{113}$ (albeit, section $10 \mathrm{~A}(2)$ 's adoption means that this exemption is qualified by the serious harm and serious financial loss tests) a position that pressure groups and commentators have argued should be followed in E\&W and Canada. ${ }^{114}$ This limitation on the right to sue, based upon a company's number of employees, can be attacked on a number of fronts.

Firstly, although the law is full of arbitrary cut-offs, which are sometimes unavoidable, or at least the best option available, there is force in Ruddock's argument that a limitation based on employee numbers is arbitrary, and likely to give rise to anomalies. ${ }^{115}$ This is demonstrated by: (i) SCAG's view that corporations are able to protect, and mitigate damage caused to, their reputations by virtue of public relations and advertising campaigns, and; (ii) The fact that SCAG's decision to allow small companies to retain the right to sue for defamation was based on the premise that 'they may be disproportionately affected by a defamatory publication and less likely to weather its consequences. ${ }^{116}$ This premise is self-defeating; SCAG says that it recognises that smaller companies may not be able to protect, and deal with attacks on, their

\footnotetext{
110 See section 7.

${ }^{111}$ NSW Government above, n7, [2.4].

112 Coe above, n1, 257.

${ }^{113}$ See Section 121(2) Civil Law (Wrongs) Act 2002; Section 8(2) Defamation Act 2006; Section 9(2) Defamation Act 2005.

${ }^{114}$ For examples from the UK relating to E\&W law see section 2. From Canada see Young above, n15, 577.

115 AGD above, n30, 38-39.

${ }^{116}$ NSW Government above, n7, [2.9].
} 
reputation in the same way as larger companies, yet it decided to set the number of employees at which the limitation applies to ten. Thus, small companies are left exposed by the current law, and will remain 'disproportionately affected.' For example, a 'small' company with ten employees would, prior to the introduction of section $10 \mathrm{~A}(2)$, be prevented from bringing an action in defamation. Its commencement means that the company would still be barred from suing in defamation unless it could prove serious harm and serious financial loss which, as argued in section 7 below, presents further, possibly insurmountable, challenges, for companies of all sizes, but would be particularly problematic for smaller companies.

This anomaly is particularly concerning when one considers that small organisations are not only, very often, inextricably linked to, and embedded within, their local communities ${ }^{117}$ but, as explained in section 4 , are not able to absorb attacks on their reputation in the same way as larger companies, as was recognised by SCAG. ${ }^{118}$ Consequently, a statement that negatively affects the reputation of a small company could cause it severe or even fatal damage. Accordingly, in Ruddock's opinion: '[i]t is difficult to see why a family business with, say, eleven employees should be forbidden to sue while another business with eight employees should not. ${ }^{119}$

A further flaw in nominating an arbitrary number to determine if a company can or cannot sue in defamation is that it is not inconceivable in today's world of boutique technology companies and social media influencers to have a company consisting of less than ten employees that is considerably wealthier than a 'larger' defendant. Furthermore, it seems unfair that, for example, a wealthy technology company employing eight people would be able to sue in defamation (subject to it satisfying section $10 \mathrm{~A}(2)$ ), whilst a family business employing ten people would be prevented from doing so by section 9. The short-sightedness of section 9 in relation to its practical application within a modern business context is further demonstrated by its focus on full-time employees and its failure to account for casual/temporary employment and the gig economy, which are not only widespread but are increasing. ${ }^{120}$ This undermines

\footnotetext{
${ }^{117}$ FSB above, n35.

118 See above, n108.

119 AGD above, n30, 38 .

${ }^{120}$ From Australia see: Jeff Borland, 'Five questions (and answers) about casual employment' The Conversation $30^{\text {th }}$ October 2018 https://theconversation.com/five-questions-and-answers-about-casual-employment-105745; From the UK see: Department for Business, Energy and Industrial Strategy, 'The characteristics of those in the gig economy' February 2018, 5

https://assets.publishing.service.gov.uk/government/uploads/system/uploads/attachment_data/file/687553/The_c haracteristics_of_those_in_the_gig_economy.pdf. In Canada, the most recent Labour Force Survey indicates that $13.3 \%$ of employees (2.1 million) worked in a temporary job in 2018, up from $11.8 \%$ (1.4 million) in 1998: https://www150.statcan.gc.ca/n1/daily-quotidien/190514/dq190514b-eng.htm.
} 
the provision's validity, as in this context it is not fit for purpose for how many businesses operate now, let alone how they will operate in the future. This has been recognised by the Council of Attorneys-General and, as result, it will be rectified by the adoption of the Model Defamation Amendment Provisions. Schedule 1[4] inserts a definition of employee that excludes volunteers but includes 'any individual (whether or not they are a contractor) who is engaged in the day to day operations of the corporation and who are subject to the control and direction of the corporation.' 121

Secondly, although larger companies do often have alternative, non-legal, resources to deal with attacks on their reputation, as suggested in section 4 they still have a reputation that is worthy of legal protection because of its value, not only to the company itself, but also its community, employees and other stakeholders. Thus, in this regard, the size of the company is irrelevant. Why should a company, regardless of its size (if it has ten or more full-time employees), have to spend more money on non-legal resources to deal with an attack on its reputation, which do not have the ultimate effect of vindicating the company's reputation in the same way as the remedies available pursuant to successful defamation proceedings? SCAG's response to this question is that these companies have alternative causes of action available to them, such as the law of malicious falsehood. However, as recognised by Ruddock, and will be discussed at section 6, these causes of action, although available to corporate claimants, are not always as appropriate as defamation. ${ }^{122}$

Thirdly, for the purposes of defamation law, publication happens when the imputation in question is read, heard or seen. ${ }^{123}$ Pursuant to section 9(1) of the 2005 Act, the time at which the respective company's number of employees is to be assessed to ascertain whether it can sue for defamation is the 'time of publication.' This creates an anomaly by virtue of the fact that where a defamatory imputation is published over a period of time, or is accessible indefinitely on the Internet or via social media, a company with a variable or transient workforce, which is very often the case with smaller companies who may take on temporary staff during busy periods, ${ }^{124}$ may have rights in respect of some, but not all publications, of identical matter. ${ }^{125}$ This is particularly concerning when considering the proliferation of review

\footnotetext{
${ }^{121}$ MDAP PCC-541 d30 above, n13, 3.

${ }^{122}$ AGD above, n30, 38-39.

${ }^{123}$ Duke of Brunswick v Harmer (1849) 14 QB 185, 117 ER 75; Loutchansky v Times Newspapers Ltd (Nos 4 and 5) [2002] QB 783, 817-818; Dow Jones \& Co Inc v Gutnick (2002) 210 CLR 575, 194 ALR 433.

${ }^{124}$ For example, over the Christmas period, or to deal with a large order or help on a short-term project.

${ }^{125}$ Collins above, n20, 450.
} 
sites, such as Google Reviews and Tripadvisor, and the lasting damage that can be done to small companies by untrue and adverse comments left on these sites. ${ }^{126}$ It seems unfair that a small company that happens to have taken on extra staff at the time that an untrue and damaging review is published, thereby temporarily taking it over the ten employee threshold is, by virtue of section 9(1), unable to use defamation to vindicate its reputation, leaving it exposed to potentially long-term damage.

Finally, section 9(2)(b) of the 2005 Act determines that the right of companies with fewer than ten employees to sue in defamation does not apply if the company is related to another company pursuant to section 50 of the Corporations Act 2001, ${ }^{127}$ regardless of whether, between them, they have less than ten employees. There are many situations in which small businesses will be related to each other yet will employ under ten employees. For example, a small, family-run chain of newsagents or takeaway restaurants could, conceivably, fall foul of this gap in the law, leaving them exposed, with no legitimate means of reputational protection.

\section{ALTERNATIVE CAUSES OF ACTION}

SCAG advanced the view that corporations do not need to rely on defamation to protect their reputation, as other causes of action are available that offer adequate protection and remedies. ${ }^{128}$ To the contrary, for the reasons set out below, it is submitted that these alternative causes of action are not always appropriate. Indeed, in Ruddock's view, restricting companies to using causes of action, such as injurious falsehood, and remedies under the Competition and

\footnotetext{
${ }^{126}$ Michael Douglas, 'Before you write that scathing online review, beware of defamation' The Conversation $19^{\text {th }}$ March 2018: https://theconversation.com/before-you-write-that-scathing-online-review-beware-of-defamation92595; Ashley Lutz, 'Restaurant Owner: My Two Star Yelp Rating Is Ruining My Small Business' Business Insider Australia 25 ${ }^{\text {th }}$ April 2013: https://www.businessinsider.com.au/owner-yelp-is-bad-for-small-business2013-4?r=US\&IR=T. In the UK, the Competition \& Markets Authority announced in May 2020 that it would require 'several major websites' to reveal how they detected, investigated and responded to fake and misleading reviews after receiving complaints that the sites were failing to stop abuse of their systems. See: https://www.gov.uk/government/news/cma-investigates-misleading-online-reviews; A. Ellson, 'Watchdog tackles shopping websites over fake reviews' The Times $23^{\text {rd }}$ May 2020, 36.

${ }^{127}$ Section 50 provides: Where a body corporate is: (a) a holding company of another body corporate; or (b) a subsidiary of another body corporate; or (c) a subsidiary of a holding company of another body corporate; the first-mentioned body and the other body are related to each other. Schedule 1[2] of the Model Defamation Provisions 2020 extends this by also excluding companies that are associated entities of other corporations from having a cause of action for defamation. Pursuant to Schedule 1[1] associated entities have the meaning prescribed by section 50AAA of the Corporations Act 2001. MDAP PCC-541 d30 above, n13, 3 .

${ }^{128}$ SCAG above, n17, 14-15.
} 
Consumer Act 2010, impose an onerous and unreasonable burden upon them that, ${ }^{129}$ arguably, results in inequality and injustice.

As stated by David Rolph, historically, allowing companies to sue in defamation conferred certain benefits on them. ${ }^{130}$ In particular, in Australia, E\&W and Canada, defamation law presumes both falsity, in that the burden is on the defendant to prove the truth of the statement, and damage to reputation ${ }^{131}$ (although in E\&W section 1 of the 2013 Act has effectively eliminated the presumption of damages ${ }^{132}$ and in Australia section 10A will have the same effect). Consequently, compared to the common law and statutory causes of action discussed below, prior to the introduction of the section 9 prohibition (and, now, section 10A(1) and (2)) in Australia, and the section 1(1) serious harm and section 1(2) serious financial loss tests in $\mathrm{E} \& \mathrm{~W}$, this made it relatively easy for companies to bring an action for defamation. This remains the case in Canada.

\section{Malicious falsehood and misleading or deceptive conduct}

As the High Court of Australia judgment in Radio 2UE Sydney Pty Limited v Chesterton ${ }^{133}$ points out, defamation protects reputation, whereas injurious falsehood protects the goods, services, business or property of the claimant, as opposed to its reputation per se. ${ }^{134}$ To maintain an action for malicious (or injurious) falsehood in all three jurisdictions the claimant must show that: (i) the defendant published to third parties words which are false; (ii) that they refer to the claimant, or their property or their business; (iii) that they were published maliciously; and (iv) that actual damage has followed as a direct and natural result of their publication. ${ }^{135}$ Unlike defamation, with malicious falsehood, the claimant bears the burden of proof in relation to the elements of falsity, malice and damage. ${ }^{136}$ Furthermore, in Australia, section 18 of Schedule 2 of the Competition and Consumer Act 2010 provides a statutory cause

\footnotetext{
${ }^{129}$ AGD above, n30, 38-39.

${ }^{130}$ Rolph above, n20, 195; Collins above, n20, 453-455.

${ }^{131}$ From Australia see: Feo v Pioneer Concrete (Vic) Pty Ltd [1999] 3 VR 417, [1999] VSCA 180, BC9908954, [57]. From the see: Jameel v Wall Street Journal Europe Sprl (No 2) [2007] 1 AC 359. From Canada see: Grant v Torstar Corporation 2009 SCC 61; [2009] 3 SCR 640, [28].

${ }^{132}$ Lachaux $v$ Independent Print Ltd [2019] UKSC 27, [20].

133 [2009] HCA 16; (2009) 238 CLR 460.

${ }^{134}$ Ibid. per French CJ, Gummow, Kiefel and Bell JJ, [12].

${ }^{135}$ For example, see: Ratcliffe v Evans [1892] 2 QB 524; Joyce v Motor Surveys Limited [1948] Ch 252; Palmer Bruyn \& Parker Pty Ltd v Parsons [2001] HCA 69; (2001) 208 CLR 388; Mahon v Mach 1 Financial Services Pty Ltd [2012] NSWSC 651.

${ }^{136}$ From Australia see: Palmer Bruyn \& Parker Pty Ltd v Parsons [2001] HCA 69; (2001) 208 CLR 388, per Gummow J at 404; Radio2UE Sydney Pty Ltd v Chesterton [2009] HCA 16; (2009) 238 CLR 460, per French CJ, Gummow, Kiefel and Bell JJ, [2009] HCA 16, 468-9. From E\&W see: Ratcliffe v Evans [1892] 2 QB 524, per Bowen LJ at 527-528. From Canada see: Lysko v. Braley (2006) 79 OR (3d) 721 (CA), [133].
} 
of action for misleading or deceptive conduct which can be employed by corporations. ${ }^{137}$ In common with malicious falsehood, a claimant wishing to rely on section 18 bears the burden of demonstrating that the publication was likely to mislead or deceive. Additionally, to obtain a remedy, they would need to sustain actual damage. ${ }^{138}$

Thus, the section 9 prohibition has effectively forced companies to employ causes of action to protect their reputation that, due to their more onerous conditions, were previously rarely used for this purpose. ${ }^{139}$ As argued above, and explored in more detail at section 7 below, the introduction of section $10 \mathrm{~A}(2)$ is unlikely to change this in many cases. For the purposes of reputational protection Orion Pet Products Pty Ltd $v$ RSPCA ${ }^{140}$ animates the disparity between the law of defamation, as compared to malicious falsehood and misleading or deceptive conduct. ${ }^{141}$ Orion sued the RSPCA because of comments it made that Orion's electronic dog collars were cruel and ineffective. ${ }^{142}$ The claim for malicious falsehood failed because, although false, the RSPCA's statements were not malicious. ${ }^{143}$ The misleading or deceptive conduct claim also failed because, according to the court, the RSPCA's claims were genuinely held opinions which were not devoid of any foundation ${ }^{144}$ and, in any event, were published for public education purposes, rather than in the course of trade or commerce. ${ }^{145}$ To the contrary, the defamation claim succeeded. ${ }^{146}$ This was due to it being relatively easy for Orion to establish defamation, but more difficult for the RSPCA to make out their pleaded defences of justification, fair comment and qualified privilege, which were all rejected by the court. $^{147}$

\footnotetext{
137 The Australian Consumer Law (ACL) is contained within Schedule 2 of the 2010 Act. Section 18 enshrines Section 52 of the Trade Practices Act 1974 into the ACL.

138 Section 82 Competition and Consumer Act 2010.

${ }^{139}$ In respect of malicious falsehood, see Alastair Mullis and Richard Parkes QC (eds), Gatley on Libel and Slander (12th edn, Sweet \& Maxwell 2013) [21.1]-[21.3].

140 (2002) 120 FCR 191, [2002] FCA 860. See also National Auto Glass Supplies (Australia) Pty Ltd v Neilsen \& Moller Autoglass (NSW) Pty Ltd (No. 8) [2007] FCA 1625.

${ }^{141}$ For an example of how the courts have attempted to prevent companies from trying to circumvent the prohibition on their right to sue in defamation see AAMAC Warehousing \& Transport Pty Ltd $v$ Fairfax Media Publications Pty Ltd [2009] NSWSC 970;Coe above, n1, 260; Rolph above, n20, 199.

${ }_{142}$ Orion above, n140, per Weinberg J, 195-8.

${ }^{143}$ Ibid. 227.

${ }^{144}$ Ibid. $213-5$.

${ }^{145}$ Ibid. 223.

${ }^{146}$ Ibid. 238. Orion was awarded $\$ 85,000$ in damages.

${ }^{147}$ Ibid. 232-5.
} 


\section{THE EFFICACY OF THE SERIOUS FINANCIAL LOSS TEST}

In $\mathrm{E} \& \mathrm{~W}$, section 1(1) of the 2013 Act provides that for a statement to be defamatory it must have caused, or is likely to cause, the claimant's reputation serious harm. For bodies that 'trade for profit' this is qualified by section 1(2), which says that to meet this threshold companies need to demonstrate that the statement has caused, or is likely to cause, serious financial loss. Neither serious harm nor serious financial loss are defined by the Act. Rather, it has been left to case law to provide guidance on what they mean. Despite this, as explained in section 1 , in Australia, the Council of Attorneys-General used section 1(1) and 1(2), and its judicial interpretation, as its model for the section 10A(1) and (2) tests. Thus, through recourse to case law the remainder of this section will consider the efficacy of the actual or likely serious financial loss test as it applies in E\&W and will potentially apply in Australia. ${ }^{148}$

\section{(a) Actual or likely serious financial loss}

Pursuant to E\&W case law there are four methods for demonstrating serious financial loss. The first three methods relate to 'tangible' financial loss, whereas the fourth method is more abstract, in that it relates to 'reputational' loss that can result in financial loss.

The paradigm example is direct financial loss, in which the claimant may seek to prove direct losses caused by the impact of the defamatory statement on customers or clients. ${ }^{149}$ Money spent by the claimant on mitigating the damage caused by the statement by, for instance, employing a public relations consultant, ${ }^{150}$ or engaging in 'counter-publicity', has also been used successfully as evidence to satisfy the test. ${ }^{151}$ Arguably, wasted management time spent dealing with the problems caused by the defamatory statements could also be used, although this method is relatively untested. ${ }^{152}$ Finally, it is submitted that there is precedent, from the

\footnotetext{
${ }^{148}$ For analysis of the serious harm test see: Emma Linch, 'Defamation Update: Serious Harm, Lachaux and Beyond' Inforrm $4^{\text {th }}$ December 2019 https://inforrm.org/2019/12/04/defamation-update-serious-harm-lachauxand-beyond-emma-linch/.

${ }^{149}$ Pursuant to Undre v Harrow [2017] EMLR 3 the losses incurred must relate to a reduction in profit, as opposed to turnover. However, such loss can be inferred from relatively slim materials. See Brett Wilson LLP v Persons Unknown [2016] 4 WLR 69.

${ }^{150}$ ReachLocal UK Ltd v Bennett [2015] EMLR 7.

${ }^{151}$ By analogy, see Lisle-Mainwaring v Associated Newspapers Ltd \& Anor [2017] EWHC 543 (QB), [131][180].

${ }^{152} R+V$ Versicherung $v$ Risk Insurance \& Reinsurance Solutions SA \& Others [2006] EWHC 42 (Comm); Hugh Tomlinson QC and Guy Vassall-Adams QC (eds), Online Publication Claims: A Practical Guide (Matrix Chambers 2017), [5.34].
} 
E\&W courts ${ }^{153}$ and, to an extent, the European Court of Human Rights, ${ }^{154}$ for a reduction in balance sheet 'goodwill', that reflects damage to the corporate name and brand, and amounts to a loss suffered by the company, ${ }^{155}$ being used to demonstrate serious financial loss. However, this is subject to academic debate and judicial conflict. ${ }^{156}$

On the face of it, demonstrating that actual or likely serious financial loss has been incurred should be relatively straightforward, especially where one of the first three methods relating to 'tangible' financial loss has been employed. However, in practice, this is not the case. Rather, as discussed below, due to difficulties with establishing causation, particularly with the more abstract fourth method, the provision presents a formidable, and very often insurmountable, hurdle for corporate claimants to overcome, particularly smaller companies that do not have the same financial and legal resources at their disposal as larger companies and many defendant organisations.

\section{(b) Establishing causation: 'tangible' financial loss}

In relation to tangible financial loss, it is submitted that there are two issues which, in some instances, may prove insurmountable for corporate claimants.

Firstly, the claimant will need to establish causation by demonstrating that the defamatory statement caused or is likely to cause serious financial loss. This would not be an issue where, for example, there is one statement clearly linked to an immediate drop in profits. However, difficulty arises where a loss has been caused by a number of statements, only one, or a selection, of which, is actionable. In this example, to establish causation, the claimant would have to prove that the single defamatory statement caused or is likely to cause 'a' serious financial loss. The second issue is quantifying the loss caused, or likely to be caused, from that individual, or selection of, defamatory statement(s). In this example, it may prove impossible

\footnotetext{
${ }^{153}$ For example, see: $R$ (Nicholds) v Security Industry Association [2006] EWHC 1792 (Admin), per Kenneth Parker QC, [72] and [73]; R (Malik) $v$ Waltham Forest NHS Primary Care Trust [2007] EWCA Civ 265, per Auld $\mathrm{J}$ at [23] and [42].

154 There is a line of Strasbourg jurisprudence, beginning with Van Marle v Netherlands App. Nos 8543, 8674, 8675 and 8685/79 (1986) 8 EHRR 483, [63], that determines that the goodwill of a professional practice, or of a 'business engaged in commerce', can be a possession for the purposes of Article 1 Protocol 1 of the ECHR. See: Peter Coe and James Brown, 'What's in a Name? The Case for Protecting the Reputation of Businesses under Article 1 Protocol 1 of the European Convention on Human Rights' (2019) Journal of European Tort Law 10(3), 286-315.

155 To the contrary, pursuant to Collins Stewart v Financial Times Ltd [2005 EMLR 5, reduction in share value is not sufficient as share price is not an aspect of goodwill or an asset of the company (see also Dillon LJ's judgment in Lonrho v Fayed (No. 5) [1994] 1 ALL ER 188196 (a)-(g)).

${ }^{156}$ For analysis of the conflicting case law, particularly from the European Court of Human Rights, see Coe and Brown above, n154.
} 
for a company to separate what loss is linked to the untrue actionable statement(s) and what is linked to other, non-actionable statements, that have caused legitimate damage to its reputation. ${ }^{157}$ Thus, in some instances, corporate claimants will be in the unfortunate position of not only facing a protracted and costly challenge to establish a causative link between a statement and their actual or likely financial loss, but may also suffer further negative publicity as a result their attempt to vindicate their reputation through such protracted litigation. ${ }^{158}$

Secondly, serious financial loss to one company would be a minor dent on the balance sheet of another. Quantifying serious financial loss in any given case, particularly where that loss is potential as opposed to real, ${ }^{159}$ will be difficult. To date there is no guidance as to what the word 'serious' means within the context of the section 1(2) test. However, it is submitted that, logically, it should be subject to the same interpretation as Section 1(1), albeit what amounts to 'serious' financial loss should be relative to the size of the company. ${ }^{160}$

\section{(c) Establishing causation: 'loss of goodwill'}

Section 1(2) and section 10A(2) may prevent companies from pursuing legitimate claims where their reputation has been damaged. For example, a company may undertake not-for-profit activities as part of its corporate social responsibility (CSR) policy. A defamatory statement in relation to these activities may not cost the claimant money in the same way as the examples set out in the previous section, but it could depreciate its goodwill, thereby affecting it in its 'way of business' ${ }^{161}$ In this example, the loss may manifest as an inability to continue certain CSR activities, which may, in turn, impact upon the company's ability to attract and recruit talented employees. ${ }^{162}$ Incidentally, a damaged reputation relating to this type of activity could also interfere with marketing campaigns or staff development plans, all of which could have an eventual impact on the financial health and prosperity of the company. ${ }^{163}$ Thus, although, in theory, quantifiable economic loss may be caused by, for instance, not being able recruit good employees, due to the nature of goodwill being inherently intangible, measuring and quantifying the loss and establishing causation with any precision is likely to be an extremely

\footnotetext{
${ }^{157}$ Although mainly concerning malicious falsehood, this point is illustrated by Tesla Motors Limited and Another v British Broadcasting Corporation [2013] EWCA Civ 152, per Moore-Bick LJ, [46].

158 Ibid. [44].

159 See the fourth 'abstract' method for demonstrating serious financial loss (a reduction in balance sheet 'goodwill') at section 7(a) above.

160 Tomlinson and Vassall-Adams above, n152, [5.34].

${ }^{161}$ Derbyshire County Council v Times Newspapers Ltd [1992] QB 770, 546 per Lord Keith.

162 Andrew Keay, Directors' Duties (2nd edn, Jordans 2014), 157; Larry Ribstein, 'Accountability and Responsibility in Corporate Governance’ (2006) 81 Notre Dame Law Review 1431, 1457-1458.

163 Ibid.
} 
difficult hurdle for a claimant to overcome, both practically and economically: in this case, demonstrating actual or likely serious financial loss by virtue of the loss of goodwill may only be achieved by, for example, establishing a link between the statement and consequent inability to recruit suitable employees which causes economic harm. Evidentially this would be hugely challenging, particularly for smaller companies with less financial means and legal resources, as it would be subject to issues of remoteness, reliability, and certainty, due to the variable factors that would be involved. ${ }^{164}$

\section{(d) A road to nowhere?}

Not all corporations that have been subject to alleged defamatory imputations are in a sufficient financial position to fund prolonged litigation, even if they have a realistic prospect of succeeding. ${ }^{165}$ To the contrary not all defendants are financially disadvantaged, as they may, for instance, include large media corporations. ${ }^{166}$ Consequently, where the claimant is a small company there is arguably significant potential for the section 1(2) and section 10A(2) serious financial loss qualifications to disproportionately disadvantage corporate claimants. This added complexity of proving actual or likely serious financial loss only serves to lengthen litigation further. The acute difficulty with establishing causation means that corporate claimants face the prospect of having their claims struck out, due to their being no reasonable grounds disclosed for bringing the claim, pursuant to rule 3.4(2)(a) of the E\&W Civil Procedure Rules (CPR), and for displaying no reasonable cause of action pursuant to rule 14.28 of the Uniform Civil Procedure Rules (UCPR) in Australia. Equally, E\&W claimants are exposed to 24.2 CPR applications for summary judgment, on the basis that there is no real prospect of being able to demonstrate at trial that it has suffered any quantifiable loss by reason of actionable statements. ${ }^{167}$ For the same reasons, in Australia, claimants will be exposed to rule 13.4(1) UCPR summary dismissal applications.

Consequently, it is submitted that the threat of increasingly protracted litigation, and the sheer complexity of establishing that the serious harm caused to the company's reputation emanated from a particular statement, will deter some companies, particularly smaller entities, from pursuing a defamation claim, even if they have a realistic (or better) prospect of

\footnotetext{
${ }^{164}$ For example, establishing that a potential employee chose to look elsewhere for employment due to the defamatory statement; or, that an employee's performance is below that of a potential employee who would have applied for a position within the company, but for the statement, and that performance shortfall has had, or is likely to have, a negative financial impact.

${ }^{165}$ Gary Chan, 'Corporate Defamation: Reputation, Rights and Remedies' (2013) 33(2) Legal Studies 268, 281.

166 Ibid.

${ }^{167}$ See Tesla above n157; Coe above, n29, 332-333.
} 
succeeding, due to the costs involved and the resources required. The position is worse for corporate claimants where they have suffered a loss of goodwill. In these situations, it will be practically very difficult and / or simply uneconomic, to attempt vindicate their reputation using defamation.

Ultimately, this may result in claims for defamation being brought by individuals associated with the 'defamed' company, such as the Chief Executive Officer (CEO), or an individual named in the alleged defamatory statement. In this instance, unless it was clear that the allegation only criticised the company, the individual could argue that the statement identified and defamed them. Notwithstanding the fact that this is more likely to occur with smaller companies, where individuals are more closely associated with the company itself, by bringing an action in this way the serious financial loss requirement is circumvented, although the individual would still have to satisfy the serious harm requirement. This is not an ideal situation for two reasons. Firstly, if the individual is successful, damages may be recovered. However, because the action would have been brought by the individual rather than the company, its reputation is less likely to have been explicitly vindicated. Secondly, claims brought by an individual, such as the CEO, effectively suing to seek vindication of the company's reputation, may be treated by the courts as an abuse of process. ${ }^{168}$

\section{CONCLUSION: ELIMINATING THE PRESUMPTION OF FALSITY FOR CORPORATE DEFAMATION CLAIMANTS - AN ALTERNATIVE WAY FORWARD?}

The use of SLAPP litigation by Canadian corporations to silence defamatory and nondefamatory criticism of businesses animates the need for a regime that is more protective of speech about corporations and corporate conduct than is currently in place in Canada. To the contrary, using an arbitrary number of employees to determine which companies can and cannot sue in defamation is problematic. In the case of the section 9 prohibition, it provides inadequate protection for companies generally and, particularly, for many typical small companies. Yet, paradoxically, it can disproportionately protect small yet wealthy companies (subject to overcoming the section 10A(2) serious harm and serious financial loss tests). It has also been asserted that removing the presumption of damage, and requiring claimants to prove they have suffered actual or likely serious financial loss creates what can be potentially

168 Coe above, n29, 332. 
insurmountable hurdles to establishing causation for companies of all sizes, but are particularly difficult for smaller companies to overcome. This is because: (i) larger companies are able to use non-legal methods which are not typically available to smaller companies; (ii) smaller companies do not have the financial and legal resources to help them overcome the challenges presented by the serious financial loss qualification.

However, it is easy to assert that, on the one hand, the Canadian position overprotects corporations, and on the other hand, the Australian and E\&W positions disproportionately disadvantage businesses. Much more challenging questions to answer are: how can a balance between protecting corporate reputation using defamation and protecting free speech be achieved and, therefore, what alternative is there to the Canadian, Australian and E\&W approaches that could create a more appropriate balance between these conflicting interests?

According to Milo the presumption of falsity in favour of defamation claimants illustrates the "primacy of reputation over free speech at common law. ${ }^{\text {, }}{ }^{169}$ It is submitted that a way to achieve a more appropriate balance between these interests would be to eliminate the presumption of falsity for corporate defamation claimants; ${ }^{170}$ thereby reversing the existing burden of proof by requiring businesses to establish that a defamatory statement of fact is untrue, or that a defamatory comment is unfair. At first glance this suggestion may seem to contradict the arguments made earlier in this article relating to the appropriateness of injurious falsehood as an alternative cause of action to defamation. ${ }^{171}$ However, unlike injurious falsehood, which presents claimants with the onerous requirement of proving three 'elements': falsity, maliciousness and damage, this would only require falsity to be established. It is submitted that, unlike proving damage by establishing actual or likely serious financial loss, which we have seen creates significant challenges for claimants, this would not be an unsurmountable hurdle for businesses with genuine claims to overcome. ${ }^{172}$ Indeed, this is borne out by empirical research from the United States following the case of Philadelphia Newspapers Incorporated $v$ Hepps $^{173}$ in which it was found that, in a substantial number of cases, claimants were successful in establishing falsity, or at least raising material issues

\footnotetext{
${ }^{169}$ Milo above, n95, 168.

170 This corresponds with the position in the United States. See: Philadelphia Newspapers Incorporated et al $v$ Hepps et al 475 US 767 (1986). However, in Canada, it was said in Pressler v Lethbridge (1997) 153 DLR (4 $\left.{ }^{\text {th }}\right)$ 537 that the common law presumption of falsity does not violate the Canadian Charter of Rights, and is too well established to be changed except by the Supreme Court (Bank of British Columbia v Canadian Broadcasting Corporation (1993) 108 DLR $\left(4^{\text {th }}\right)$ 178).

${ }^{171}$ See section 6.

172 Milo above, n95, 166-167.

173475 US 767 (1986).
} 
relating to falsity that enabled them to resist summary judgment applications. ${ }^{174}$ Consequently, it would provide an appropriate 'check and balance' mechanism on corporations that protects free speech whilst, at the same time, not presenting an overly burdensome hurdle for businesses with meritorious claims to overcome.

It is submitted that requiring corporate claimants to establish the falsity of a statement or the unfairness of a comment can benefit businesses in a way that is not immediately obvious. The presumption of falsity means that the onus is on the defendant to prove truth or fairness. If they are unable to do this then it is presumed that the statement is false or unfair. Under these circumstances the claimant essentially remains 'in neutral' and does not have to proactively vindicate their reputation. It is not inconceivable that from an outsider's perspective (and for companies this could mean their current or potential customers or clients) this may appear as though the only reason the claimant was successful was because the defendant was unable, in that instance, to establish truth or fairness, as opposed to the statement or comment definitively being untrue or unfair. Therefore, this can result in negative as opposed to positive victories for claimants, as although they have technically won the case, their reputations are not objectively vindicated. To the contrary, a proactive requirement on claimants to prove truth or fairness overcomes this issue with 'negative victories.' 175

In conclusion, the distinct approaches adopted in Australia, E\&W and Canada are problematic because they either over-protect corporate reputation, or disproportionately disadvantage companies, particularly small ones. Striking a perfect balance between appropriately protecting corporate reputation and protecting free speech is, probably, impossible. Rather, the best we can hope for is an imperfect balance using what is an imperfect solution. However, it is submitted that for the reasons advanced in this article the alternative way forward that it has been suggested above achieves a better balance for both rights than is currently the case in all three jurisdictions.

\footnotetext{
${ }^{174}$ Brian J. Steffan 'The Falsity Burden of Private Libel Plaintiffs since Philadelphia Newspapers, Inc v Hepps' (1994) 16(3) Communications and the Law 57-82.

${ }^{175}$ In Post's view '[t]he issue of truth is essential to a plaintiff's rehabilitation...': Post above, n84, 713; Lawrence McNamara, Reputation and Defamation (Oxford University Press, 2007), 52.
} 